\title{
PENGARUH PENERAPAN POLA DIET DASH (Dietary Approaches To Stop Hypertension) TERHADAP TEKANAN DARAH SISTOLIK DAN DIASTOLIK PADA KELOMPOK LANSIA DI KOTA SEMARANG
}

\author{
Nadya Syafa Nurhumaira, Hesti Murwani Rahayuningsih") \\ Program Studi Ilmu Gizi Fakultas Kedokteran Universitas Diponegoro \\ J1.Dr.Sutomo No.18, Semarang, Telp (024) 8453708, Email : gizifk@ undip.ac.id
}

\begin{abstract}
Background: Hypertension is one of the risk factors for the incidence of comorbidities in cardiovascular, renal and brain system. An increase in prevalence of hypertension is directly proportional with the increase in age. One of the efforts to control hypertension in the elderly group is dietary choice as listed in the DASH eating pattern.

Methods: This was a true experimental study with the pre-post test control group design. A total of 17 elderly subjects with systolic blood pressure 120-200 $\mathrm{mmHg}$ and diastolic blood pressure 80-120 mmHg were divided into 2 groups. The intervention was conducted by giving the food based on the DASH eating pattern three times a day for 14 days. Subjects in the control group consumed a usual dietary pattern. Blood pressure was measured using an aneroid sphygmomanometer one day before and after intervention. Food intake during intervention was obtained using a food recall method. Data was analyzed using Shapiro-Wilk, paired-t test, and Wilcoxon.

Reuslts: In the DASH group, mean systolic and diastolic blood pressure before intervention was $138.57 \mathrm{mmHg}$ and $84.29 \mathrm{mmHg}$, respectively. After intervention, mean systolic and diastolic blood pressure in this group was 144.29 $\mathrm{mmHg}$ and $82.86 \mathrm{mmHg}$. There was no difference in systolic and diastolic blood pressure before and after the intervention for 14 days.

Conclusion: There was no effect of implementing the DASH eating pattern for 14 days on both systolic and diastolic blood pressure in the elderly group.
\end{abstract}

Keywords: the DASH eating pattern; systolic blood pressure; diastolic blood pressure; hypertension; elderly

\begin{abstract}
ABSTRAK
Latar Belakang: Hipertensi merupakan salah satu faktor risiko terjadinya komorbid pada sistem kardiovaskular, ginjal dan otak. Peningkatan prevalensi hipertensi berbanding lurus dengan peningkatan usia. Salah satu upaya pengendalian hipertensi pada kelompok lansia adalah melalui pemilihan pola makan seperti pola diet DASH. Metode: Jenis penelitian ini adalah true experimental dengan rancangan pre-post test control group design. Sebanyak 17 lansia dengan tekanan darah sistolik 120-200 mmHg dan tekanan darah diastolik 80-120 mmHg dibagi menjadi 2 kelompok. Intervensi berupa pemberian makanan sesuai pola diet DASH sebanyak 3 kali sehari selama 14 hari. Kelompok kontrol mengkonsumsi pola makan sehari-hari. Tekanan darah diukur menggunakan sphygmomanometer aneroid satu hari sebelum dan setelah intervensi. Asupan makan selama intervensi diperoleh dengan metode food recall. Analisis data menggunakan Shapiro-Wilk, paired-t test dan Wilcoxon.

Hasil: Pada kelompok perlakuan, rerata tekanan darah sistolik dan diastolik awal sebelum dilakukan intervensi masing-masing adalah $138.57 \mathrm{mmHg}$ dan $84.29 \mathrm{mmHg}$. Rerata tekanan darah sistolik dan diastolik setelah dilakukan intervensi masing-masing adalah $144.29 \mathrm{mmHg}$ dan $82.86 \mathrm{mmHg}$. Tidak ada perbedaan tekanan darah sistolik dan diastolik sebelum dan setelah intervensi selama 14 hari.
\end{abstract}

Kesimpulan: Tidak terdapat pengaruh penerapan pola diet DASH selama 14 hari terhadap tekanan darah sistolik dan diastolik pada kelompok lansia.

Kata Kunci: pola diet DASH; tekanan darah sistolik; tekanan darah diastolik; hipertensi; lansia

\section{PENDAHULUAN}

Hipertensi merupakan salah satu penyakit degeneratif yang memiliki tingkat morbiditas dan mortalitas yang tinggi. ${ }^{1,2}$ Tekanan darah tinggi merupakan faktor risiko yang kuat terhadap terjadinya penyakit ginjal dan penyakit-penyakit kardiovaskular seperti stroke dan penyakit jantung iskemik. Individu prehipertensif memiliki kemungkinan tinggi mengalami hipertensi dan peningkatan risiko mengalami penyakit kardiovaskular dibandingkan individu dengan nilai tekanan darah dalam kisaran normal. ${ }^{3-6}$
Kejadian hipertensi secara global cenderung meningkat, terutama di negara maju dan negara berkembang yang sedang mengalami transisi epidemiologi ${ }^{7,8}$ Berdasarkan hasil Riskesdas 2013, prevalensi hipertensi pada tahun 2013 secara nasional sebesar 25.8\%. Prevalensi hipertensi di Jawa Tengah pada penduduk berusia $\geq 18$ tahun sebesar $26.4 \%$. Peningkatan prevalensi hipertensi berbanding lurus dengan peningkatan usia. ${ }^{9,10}$ Di Amerika, prevalensi hipertensi paling tinggi ditemukan pada penduduk usia $\geq 60$ tahun yaitu sebesar $65 \%$. Pada tahun 2013, prevalensi 
penduduk berusia 65-74 tahun di Indonesia yang mengalami hipertensi sebesar 57.6\%. ${ }^{9}$ Prevalensi hipertensi lebih tinggi pada pria hingga usia 55 tahun, namun demikian sedikit lebih tinggi pada wanita postmenapouse. ${ }^{5,6,7}$ Terapi medikamentosa untuk mengendalikan tekanan darah telah banyak dilakukan, namun jika obat-obatan terus diberikan pada kelompok lansia yang telah mengalami penurunan fungsi organ, salah satunya ginjal, ${ }^{11,12}$ maka akan memperberat fungsi organ tersebut. Oleh karena itu, dilakukan upaya lain untuk membantu mengendalikan hipertensi khususnya pada kelompok lansia, salah satunya dengan pemilihan pola makan seperti yang tercantum dalam pola diet DASH (Dietary Approaches To Stop Hypertension).

Pola diet DASH merupakan pola diet yang menekankan pada konsumsi bahan makanan rendah natrium $(<2300 \mathrm{mg} / \mathrm{hari})$, tinggi kalium (4700 mg/hari), magnesium ( $>420 \mathrm{mg} /$ hari $)$, kalsium(>1000 mg/hari), dan serat $(25-30 \mathrm{~g} / \mathrm{hari})$ serta rendah asam lemak jenuh dan kolesterol ( $<200 \mathrm{mg} /$ hari) yang banyak terdapat pada buah buahan, kacang-kacangan, sayuran, ikan, daging tanpa lemak, susu rendah lemak, dan bahan makanan dengan total lemak dan lemak jenuh yang rendah. ${ }^{13}$ Bahan makanan yang terdapat dalam pola diet DASH merupakan bahan makanan segar dan alami tanpa melalui proses pengolahan industri terlebih dahulu sehingga memilki kadar natrium yang relatif rendah.,15 JNC (Joint National Committee on Prevention,Detection, Evaluation, and Treatment of High Blood Pressure) VII tahun 2003 telah mengesahkan pola diet DASH sebagai salah satu upaya dalam mencegah peningkatan tekanan darah pada subjek hipertensi. ${ }^{16}$ Pola diet DASH yang terdiri dari konsumsi bahan makanan diatas terbukti secara klinis menurunkan tekanan darah secara signifikan dengan atau tanpa pengurangan asupan natrium. ${ }^{13,14}$ Bahan makanan yang terdapat dalam pola diet DASH adalah produk serealia dan biji-bijian sebanyak 7-8 penukar per hari, sayuran sebanyak 4-5 penukar per hari, buah-buahan 4-5 penukar per hari, produk susu rendah atau tanpa lemak 2-3 penukar per hari, ikan, daging dan unggas tidak lebih dari 2 penukar per hari, kacang-kacangan 4-5 penukar per minggu, minyak 2-3 penukar dalam sehari dan pemanis 5 penukar per minggu. ${ }^{5}$

Terdapat beberapa penelitian mengenai pengaruh penerapan pola diet DASH terhadap tekanan darah. Penelitian pada orang dewasa prehipertensi dan hipertensi tahap I menguji pengaruh penerapan pola diet DASH tanpa perubahan perilaku dalam keadaan free - living environment. Hasil dari penelitian ini adalah terdapat penurunan nilai tekanan darah sistolik secara signifikan pada kelompok perlakuan yaitu sebesar $10.6 \mathrm{mmHg}$, namun tidak pada tekanan darah diastolik, yaitu sebesar $2.2 \mathrm{mmHg}^{.14}$ Penelitian lain yang diberi nama "Encore Study" membandingkan pengaruh penerapan pola diet DASH saja atau pola diet DASH yang dikombinasikan dengan program pengendalian berat badan dengan pola diet yang biasa dikonsumsi di Amerika pada subjek prehipertensi atau hipertensi tahap I. Hasil dari penelitian ini adalah terdapat penurunan nilai tekanan darah sebesar 16.1/9.9 mmHg pada intervensi pola diet DASH yang dikombinasikan dengan pengendalian berat badan, penurunan sebesar 11.2/7.5 $\mathrm{mmHg}$ pada intervensi pola diet DASH saja dan penurunan sebesar 3.4/3.8 mmHg pada kelompok kontrol. ${ }^{17}$ Penelitian di Indonesia membandingkan antara penerapan pola diet DASH dikombinasikan diet rendah garam (DRG) dengan penerapan diet rendah garam (DRG) saja pada wanita menopouse dengan hipertensi. Hasilnya adalah kombinasi penerapan pola diet DASH dan diet randah garam (DRG) menurunkan rerata tekanan darah sistolik dan diastolik masing-masing sebesar $5.23 \mathrm{mmHg}$ dan $1.98 \mathrm{mmHg}$. Sedangkan diet rendah garam (DRG) saja dapat menurunkan rerata tekanan darah sistolik dan diastolik masing-masing sebesar 2.5 $\mathrm{mmHg}$ dan $1.75 \mathrm{mmHg} .{ }^{18}$

Meskipun terdapat beberapa bukti bahwa penerapan pola diet DASH dapat menurunkan tekanan darah, penelitian mengenai pengaruh penerapan pola diet DASH terhadap tekanan darah pada kelompok lansia belum pernah dilakukan. Hal ini yang mendasari dilakukannya penelitian ini untuk menguji pengaruh penerapan pola diet DASH terhadap tekanan darah sistolik dan diastolik pada kelompok lansia.

\section{METODE}

Penelitian dilakukan di Panti Werdha Rindang Asih II Semarang pada bulan April 2014. Subjek penelitian ini adalah kelompok lansia lakilaki dan perempuan dengan usia diatas 60 tahun yang mengalami prehipertensi, hipertensi tahap I dan hipertensi tahap II dengan rentang nilai tekanan darah sistolik sebesar $120-200 \mathrm{mmHg}$ dan rentang nilai tekanan diastolik sebesar 80 $\mathrm{mmHg}-120 \mathrm{mmHg},{ }^{19}$ dengan nilai IMT berkisar antara $15.0-27.9 \mathrm{~kg} / \mathrm{m}^{2},{ }^{4,5}$ tidak merokok, ${ }^{5,20}$ tidak sedang mengkonsumsi alkohol 4,5,21,22 dan suplemen multivitamin dan mineral yang mengandung unsur kalium, magnesium, kalsium ${ }^{2,23}$ maupun obat-obatan antasida, memiliki jumlah 
gigi minimal sebanyak 20 buah atau masih memiliki gigi geraham, ${ }^{24}$ bersedia menjadi sampel penelitian dan memiliki tingkat aktifitas fisik pada kategori sedang, yaitu sebanyak $40 \%$ dari waktu yang digunakan dalam satu hari adalah untuk duduk atau berdiri dan $60 \%$ untuk kegiatan khusus dalam bidang pekerjaannya. ${ }^{25}$ Kriteria eksklusi yang ditetapkan meliputi asupan makan subjek kurang dari $80 \%$ selama lebih dari tujuh hari, mengundurkan diri dari penelitian dan meninggal dunia selama proses penelitian. Perhitungan besar sampel minimal penelitian menggunakan rumus uji hipotesis terhadap rerata dua kelompok yang tidak berpasangan ${ }^{26}$ dan dibutuhkan subjek penelitian sebanyak 17 orang. Metode pemilihan sampel dilakukan dengan cara convenient sampling.

Sebelum intervensi, dilakukan skrinning terhadap 29 lansia di panti tersebut untuk memperoleh data tekanan darah, berat badan dan tinggi badan. Sebanyak 17 orang memenuhi kriteria inklusi untuk menjadi subjek penelitian. Setelah itu dilakukan pembagian subjek ke dalam dua kelompok secara acak dengan cara menghitung jumlah suku kata yang terdapat dalam nama peneliti. Delapan lansia dimasukkan ke dalam kelompok perlakuan dan sembilan lansia ke dalam kelompok kontrol. Namun, satu orang yang telah ditetapkan menjadi subjek dalam kelompok perlakuan menyatakan tidak bersedia untuk diberikan intervensi. Oleh karena itu, jumlah subjek dalam kelompok perlakuan menjadi tujuh orang dan dalam kelompok kontrol menjadi sepuluh orang. Kelompok perlakuan adalah kelompok yang menerima intervensi berupa penerapan pola diet DASH sedangkan kelompok kontrol adalah kelompok yang hanya mengkonsumsi pola makan sehari-hari. Intervensi berupa pemberian makanan sesuai dengan pola Diet DASH sebanyak tiga kali dalam sehari, yaitu pada waktu makan utama pagi, siang dan sore. Distribusi makanan untuk makan pagi adalah pada pukul $06.00-06.30 \mathrm{WIB}$, makan siang pada pukul 11.00 - 11.30 WIB dan makan sore pada pukul 16.00 - 16.30 WIB. Makanan selingan disediakan oleh panti lansia sebanyak dua kali dalam sehari yaitu selingan pagi yang diberikan pada pukul 08.30 - 09.00 WIB dan selingan sore yang diberikan pada pukul $15.30-16.00$ WIB.

Kelompok bahan makanan yang diberikan dengan jumlah penukar per hari adalah serealia sebanyak enam penukar, sayuran dan buah-buahan masing-masing sebanyak empat penukar, ikan, unggas dan daging rendah atau tanpa lemak tidak lebih dari dua penukar, susu rendah atau tanpa lemak sebanyak dua penukar. Sedangkan gula/pemanis dan kacang-kacangan masing-masing sebanyak lima penukar per minggu.

Penelitian yang diberi nama DASH LowSodium Diet, dengan subjek orang dewasa yang mengalami prehipertensi atau hipertensi tahap I membandingkan tiga kelompok perlakuan dimana dalam setiap kelompok dibagi secara acak menjadi dua kelompok yaitu kelompok yang mengkonsumsi pola makan yang biasa dikonsumsi dan kelompok yang mengkonsumsi pola diet DASH. Masing-masing kelompok tersebut diberikan preskripsi jumlah natrium dalam satu hari sebanyak $3.45 \mathrm{~g}, 2.3 \mathrm{~g}$ dan $1.15 \mathrm{~g}$. Hasil penelitian menunjukkan bahwa pada setiap jumlah asupan natrium, nilai tekanan darah sistolik dan diastolik mengalami penurunan yang lebih besar pada kelompok yang mengkonsumsi pola diet DASH dibanding kelompok kontrol. ${ }^{27}$ Dalam penelitian ini diperhitungkan bahwa kebutuhan natrium untuk kedua kelompok sebesar $2500 \mathrm{mg}$ dalam satu hari dan $500 \mathrm{mg}$ natrium berasal dari makanan. Sehingga natrium dari garam dapur adalah $2000 \mathrm{mg}$ atau sebanyak $5 \mathrm{~g}$ garam $\mathrm{NaCl}$. Karena pemberian intervensi berupa pola diet DASH dilakukan sebanyak tiga kali dalam satu hari, maka jumlah $\mathrm{NaCl}$ yang terdapat dalam satu kali pemberian makan adalah sebanyak $1.5 \mathrm{~g}$. Kebutuhan energi dihitung menggunakan rumus Schofield untuk memperoleh angka kebutuhan energi basal dan dikalikan dengan faktor aktifitas 1.3 hingga 1.42 untuk memperoleh angka perkiraan kebutuhan energi dalam satu hari. ${ }^{28}$ Kebutuhan protein sebesar $1 \mathrm{~g} / \mathrm{kg}$ berat badan/hari, ${ }^{29}$ kebutuhan karbohidrat sebesar 55\% dari total kebutuhan energi/hari, kebutuhan lemak sebesar 30\% dari total kebutuhan energi/hari, asam lemak jenuh $0.08 \%$ dari total kebutuhan energi/hari dan kolesterol tidak lebih dari $200 \mathrm{mg} / \mathrm{hari}^{30}$

Siklus menu yang diterapkan dalam intervensi ini adalah siklus menu empat hari. Menu dan distribusi penukar pada siklus pertama untuk makan pagi adalah nasi putih 1.5 penukar, telur mata sapi 1 penukar, tumis labu siam 1.5 penukar, tahu goreng 0.5 penukar, minyak kelapa sawit 2 penukar dan pisang 1.5 penukar. Menu dan distribusi penukar untuk makan siang adalah nasi putih 1 penukar, semur daging 0.5 penukar, sayur asem 1.5 penukar dan semangka 1 penukar. Sedangkan menu dan distribusi penukar untuk makan sore adalah nasi putih 1.5 penukar, capcai 1 penukar, ayam bakar 0.5 penukar, bakwan 1 penukar dan jeruk 1 penukar. Selingan pagi dan distribusi penukar yang diberikan adalah susu rendah lemak 1 penukar, teh manis, gula pasir 2 penukar dan bolu kukus 0.5 penukar. Sedangkan 
selingan sore dan distribusi penukar yang diberikan adalah bolu kukus 0.5 penukar.

Menu dan distribusi penukar pada siklus kedua adalah nasi putih 1.5 penukar, ca sawi putih 1.5 penukar, ayam bakar 0.5 penukar, tahu bacem 0.5 penukar dan pisang 1.5 penukar. Menu dan distribusi penukar untuk makan siang adalah nasi putih 1 penukar, bandeng presto goreng 0.5 penukar, bakso ikan 1/6 penukar, sayur sop 1 penukar dan semangka 1.5 penukar. Sedangkan menu dan distribusi penukar untuk makan sore adalah nasi putih 1.5 penukar, sayur lodeh 1.5 penukar, udang goreng 0.5 penukar, tempe bacem 0.5 penukar dan pisang 1 penukar. Selingan pagi yang diberikan adalah susu rendah lemak 1 penukar, roti pisang 1 penukar, pisang 0.5 penukar, gula pasir 2 penukar dan teh manis. Sedangkan selingan sore yang diberikan adalah roti keju 0.5 penukar.

Menu dan distribusi penukar pada siklus ketiga untuk makan pagi adalah nasi putih 1.5 penukar, oseng buncis 1.5 penukar, semur daging 0.5 penukar, tahu bacem 0.5 penukar dan jeruk 1 penukar. Menu dan distribusi penukar untuk makan siang adalah nasi putih 1 penukar, ikan kakap 0.5 penukar, sayur bening 1 penukar, jagung manis berjanggel 0.5 penukar, minyak kelapa sawit 1 penukar dan pepaya 1.5 penukar. Menu da distribusi penukar untuk makan sore adalah nasi putih 1.5 penukar, tumis gambas 1.5 penukar, ayam goreng 0.5 penukar, tempe tepung 0.5 penukar, tepung terigu $1 / 5$ penukar, minyak kelapa sawit 2 penukar dan semangka 1.5 penukar. Selingan pagi yang diberikan adalah susu rendah lemak 1 penukar, bihun goreng 1 penukar, gula pasir 2 penukar dan teh manis. Selingan sore yang diberikan adalah biskuit marie 2 keping.

Menu dan distribusi penukar pada siklus keempat untuk makan pagi adalah nasi putih 1.5 penukarm orak arik wortel 1.5 penukar, telur mata sapi 1 penukar, minyak kelapa sawit 1 penukar dan pisang 1 penukar. Menu dan distribusi penukar untuk makan siang adalah nasi putih 1 penukar, ikan kakap goreng 0.5 penukar, capcai 1 penukar, minyak kelapa sawit 1 penukar dan pepaya 1.5 penukar. Menu dan distribusi penukar untuk makan sore adalah nasi putih 1.5 penukar, gudeg tewel 1.5 penukar, tempe 0.5 penukar, semur daging 0.5 penukar dan pisang 1 penukar. Selingan pagi yang diberikan adalah susu rendah lemak 1 penukar, bubur sumsum (tepung beras) 2 penukar, gula pasir 2 penukar dan teh manis. Selingan sore yang diberikan adalah biskuit marie 2 keping.

Intervensi dilakukan selama empat belas hari. Selama kurun waktu tersebut dilakukan pencatatan asupan zat gizi untuk masing-masing kelompok yang diisi sendiri oleh peneliti. Setelah dilakukan intervensi dilakukan pengukuran tekanan darah pada kedua kelompok yang kemudian dianalisis dan dibandingkan perbedaannya.

Data yang diperoleh adalah data umum karakteristik subjek, data antropometri, asupan makan selama intervensi dan nilai tekanan darah. Data umum karakteristik subjek meliputi nama, usia, jenis kelamin, riwayat hipertensi, riwayat merokok, riwayat mengkonsumsi alkohol, dan obat-obatan yang sedang dijalani saat ini. Data data ini diperoleh melalui wawancara dengan subjek, perawat dan pengurus panti lansia. Data antropometri meliputi berat badan dan tinggi badan. Berat badan diukur menggunakan timbangan digital dengan ketelitian $0.1 \mathrm{~kg}$. Tinggi badan diperoleh dengan mengkonversi panjang rentang salah satu lengan (demi-span) menggunakan rumus Bassey sebagai berikut ${ }^{31}$ :

$$
\text { Laki }- \text { laki }=57.8+(1.40 \mathrm{x} \text { demi-span }
$$

(cm))

(cm))

$$
\text { Perempuan }=60.1+(1.35 \mathrm{x} \text { demi-span }
$$

Demi-span adalah jarak antara titik tengah lekukan sternum dan pangkal jari tengah pada lengan yang direntangkan dengan lurus., ${ }^{31,32}$ Panjang demi-span diukur menggunakan pita ukur/metlin dengan panjang $150 \mathrm{~cm}$ dan ketelitian $0.1 \mathrm{~cm}$. Data asupan makan diperoleh melalui pengamatan langsung terhadap asupan makan subjek pada kedua kelompok dan pencatatan dilakukan oleh peneliti setiap hari selama periode intervensi. Data asupan makan subjek selama periode penelitian dianalisis menggunakan program NutriSurvey for Windows 2003 untuk mengetahui nilai asupan zat gizi selama intervensi. Pengukuran tekanan darah subjek pada kedua kelompok sebelum dan setelah intervensi dilakukan oleh tenaga kesehatan. Pengukuran tekanan darah dilakukan pada saat sampel istirahat dengan istirahat $\sim 5$ menit sebelum pengukuran pada pukul 08.30 WIB dan dilakukan sebanyak tiga kali lalu diperoleh nilai reratanya. Alat yang digunakan untuk mengukur tekanan darah adalah sphygmomanometer aneroid.

Variabel bebas dalam penelitian ini adalah penerapan pola diet DASH yang diberikan sebanyak tiga kali dalam sehari selama empat belas hari. Sedangkan variabel terikat dalam penelitian ini adalah tekanan darah yaitu tekanan pembuluh nadi dari peredaran darah sistolik dan diastolik secara sistemik $^{4}$ di dalam tubuh sampel yang diukur dengan sphygmomanometer. 
Analisis deskriptif digunakan untuk menggambarkan karakteristik umum sebelum dilakukan intervensi dan data asupan makan selama dilakukan intervensi. Uji normalitas data menggunakan Shapiro-Wilk karena besar sampel penelitian adalah tujuh belas orang. ${ }^{33}$ Perbedaan nilai tekanan darah sistolik sebelum dan setelah dilakukan intervensi diuji dengan paired-t test pada kelompok perlakuan dan uji Wilcoxon pada kelompok kontrol. Perbedaan nilai tekanan darah diastolik sebelum dan setelah dilakukan intervensi diuji dengan uji Wilcoxon untuk kedua kelompok. Perbedaan pengaruh penerapan pola diet DASH terhadap nilai tekanan darah sistolik dianalisis menggunakan uji Mann-Whitney dan pengaruh penerapan pola diet DASH terhadap tekanan darah diastolik dianalisis menggunakan independent- $t$ test.

\section{HASIL PENELITIAN \\ Karakteristik Umum Subjek}

Karakteristik umum subjek yang meliputi usia, jenis kelamin, kategori IMT, kategori tekanan darah, dan konsumsi obat antihipertensi sebelum dilakukan intervensi penerapan pola diet DASH disajikan dalam tabel 1 berikut ini.

Tabel 1. Gambaran Umum Subjek Penelitian

\begin{tabular}{|c|c|c|c|c|c|}
\hline \multirow{2}{*}{ Karakteristik subjek } & \multicolumn{2}{|r|}{$\mathbf{P}$} & \multicolumn{2}{|c|}{$\mathbf{K}$} & \multirow{2}{*}{ Total $(\%)$} \\
\hline & $\mathbf{N}$ & $\%$ & $\mathbf{N}$ & $\%$ & \\
\hline \multicolumn{6}{|l|}{ Jenis kelamin } \\
\hline Laki-laki & 2 & 28.57 & 7 & 70 & $9(52.94)$ \\
\hline Perempuan & 5 & 71.43 & 3 & 30 & $8(47.06)$ \\
\hline \multicolumn{6}{|l|}{ Indeks Massa Tubuh (IMT) } \\
\hline$<18.5 \mathrm{~kg} / \mathrm{m}^{2}$ (status gizi kurang) & 3 & 42.86 & 2 & 20 & $5(29.41)$ \\
\hline $18.5-22.9 \mathrm{~kg} / \mathrm{m}^{2}$ (status gizi normal) & 2 & 28.57 & 7 & 70 & $9(52.94)$ \\
\hline$>22.9 \mathrm{~kg} / \mathrm{m}^{2}$ (status gizi lebih) & 2 & 28.57 & 1 & 10 & $3(17.65)$ \\
\hline \multicolumn{6}{|l|}{ Tekanan darah sistolik } \\
\hline Prehipertensi $(120-139 \mathrm{mmHg})$ & 3 & 42.86 & 6 & 60 & $9(52.94)$ \\
\hline Hipertensi I (140 - $159 \mathrm{mmHg})$ & 4 & 57.14 & 3 & 30 & $7(41.18)$ \\
\hline Hipertensi II ( $\geq 160 \mathrm{mmHg})$ & - & - & 1 & 10 & $1(5.88)$ \\
\hline \multicolumn{6}{|l|}{ Tekanan darah diastolik } \\
\hline Prehipertensi (80-89 mmHg) & 4 & 57.14 & 7 & 70 & $11(64.70)$ \\
\hline Hipertensi I (90-99 mmHg) & 3 & 42.86 & 2 & 20 & $5(29.41)$ \\
\hline Hipertensi II (100 mmHg) & - & & 1 & 10 & $1(5.88)$ \\
\hline \multicolumn{6}{|l|}{ Konsumsi obat antihipertensi } \\
\hline Mengkonsumsi obat & 3 & 42.86 & 3 & 30 & $6(32.29)$ \\
\hline Tidak mengkonsumsi obat & 4 & 57.14 & 7 & 70 & $11(64.70)$ \\
\hline
\end{tabular}

Keterangan: $\mathrm{P}=$ perlakuan

$\mathrm{K}=$ kontrol

Tabel 1 menunjukkan bahwa sebagian besar subjek penelitian adalah laki-laki (52.94\%), memiliki status gizi normal dengan nilai IMT 18.5 - $22.9 \mathrm{~kg} / \mathrm{m} 2$ (52.94\%), berada pada kategori prehipertensi dengan nilai tekanan darah sistolik dan diastolik masing-masing sebesar 120-139 $\mathrm{mmHg}(52.94 \%)$ dan $80-89 \mathrm{mmHg}(64.70 \%)$ dan tidak mengkonsumsi obat antihipertensi berupa amlodipine (64.71\%).

\section{Keadaan subjek penelitian sebelum intervensi}

Keadaan awal subjek penelitian yang disajikan dalam tabel 2 berikut ini untuk mengetahui homogenitas variabel pada kedua kelompok.

Tabel 2. Keadaan subjek penelitian sebelum intervensi

\begin{tabular}{llll}
\hline Variabel & Perlakuan $(\mathbf{n}=7)$ & Kontrol $(\mathbf{n}=10)$ & P \\
\hline IMT $\left(\mathrm{kg} / \mathrm{m}^{2}\right)$ & $21.07 \pm 4.295$ & $20.40 \pm 3.532$ & $0.729^{\mathrm{b}}$ \\
Tekanan darah sistolik $(\mathrm{mmHg})$ & $138.57 \pm 8.997$ & $130(120-200)$ & $0.305^{\mathrm{a}}$ \\
Tekanan darah diastolik $(\mathrm{mmHg})$ & $80(80-90)$ & $80(80-120)$ & $0.727^{\mathrm{a}}$ \\
\hline
\end{tabular}

${ }^{\mathrm{a}}$ Uji Mann-Whitney ${ }^{\mathrm{b}}$ Independent-t test 
Tabel 2 menunjukkan tidak ada perbedaan IMT, tekanan darah sistolik dan tekanan darah diastolik sebelum intervensi antara kedua kelompok $(\mathrm{P}>0.05)$.

\section{Asupan zat gizi selama intervensi}

Rerata asupan zat gizi selama intervensi yang disajikan dalam tabel 3 bertujuan untuk mengetahui perbedaan asupan energi dan zat gizi yang meliputi karbohidrat, protein, lemak, natrium, kalium, magnesium, kalsium, serat, asam lemak jenuh dan kolesterol antara kelompok perlakuan dan kelompok kontrol.

Tabel 3. Rerata asupan zat gizi selama intervensi

\begin{tabular}{llll}
\hline Variabel & Perlakuan $(\mathbf{n}=7)$ & Kontrol $(\mathbf{n}=\mathbf{1 0})$ & $\mathbf{P}$ \\
\hline Energi $(\mathrm{kkal})$ & $1026.56 \pm 83.1546$ & $723.71 \pm 58.2779$ & $0.000^{\mathrm{a}^{*}}$ \\
Karbohidrat $(\mathrm{g})$ & $175.229(155.0-227.4)$ & $101.05 \pm 13.5387$ & $0.001^{\mathrm{b}^{*}}$ \\
Protein $(\mathrm{g})$ & $38.414 \pm 4.3137$ & $22.030 \pm 1.3905$ & $0.000^{\mathrm{a}^{*}}$ \\
Lemak $(\mathrm{g})$ & $33.129 \pm 5.5298$ & $26.430 \pm 1.4197$ & $0.018^{\mathrm{a}^{*}}$ \\
Natrium $(\mathrm{mg})$ & $2284(2226.4-2302.3)$ & $2270.79 \pm 63.5331$ & $0.329^{\mathrm{b}}$ \\
Kalium $(\mathrm{mg})$ & $2340.14 \pm 21.432$ & $634.390 \pm 40.6091$ & $0.000^{\mathrm{a}^{*}}$ \\
Magnesium $(\mathrm{mg})$ & $248.529 \pm 23.9847$ & $111.50(89.7-120.6)$ & $0.001^{\mathrm{b}^{*}}$ \\
Kalsium $(\mathrm{mg})$ & $582.371 \pm 99.3258$ & $175.57 \pm 8.5756$ & $0.000^{\mathrm{a}^{*}}$ \\
Serat $(\mathrm{g})$ & $15.700(12.9-16.4)$ & $5.140 \pm 0.4326$ & $0.001^{\mathrm{b}^{*}}$ \\
Asam lemak jenuh $(\mathrm{g})$ & $17.529 \pm 3.4841$ & $13.200(12.7-18.7)$ & $0.014^{\mathrm{b}^{*}}$ \\
Kolesterol (mg) & $135.200(100.9-142.6)$ & $121.110 \pm 13.2482$ & $0.379^{\mathrm{b}}$ \\
\hline
\end{tabular}

${ }^{a}$ Independent-t test ${ }^{b}$ Uji Mann-Whitney "beda bermakna

Tabel 3 menunjukkan tidak terdapat lemak, kalium, magnesium dan kalsium selama perbedaan asupan natrium dan kolesterol selama intervensi antara kelompok perlakuan dan intervensi antara kelompok perlakuan dan kelompok kontrol $(\mathrm{P}<0.05)$.

kelompok kontrol $(\mathrm{P}>0.05)$. Namun terdapat Pengaruh penerapan pola diet DASH terhadap perbedaan asupan energi, karbohidrat, protein, tekanan darah sistolik dan diastolik

Tabel 4. Karakteristik tekanan darah sistolik subjek setelah intervensi

\begin{tabular}{lllll}
\hline Kelompok & $\begin{array}{l}\text { Mengalami } \\
\text { penurunan }\end{array}$ & $\%$ & $\begin{array}{c}\text { Tidak mengalami } \\
\text { penurunan }\end{array}$ & \multicolumn{1}{c}{$\%$} \\
\hline Perlakuan & 2 & 28.57 & 5 & 71.43 \\
Kontrol & 2 & 20 & 8 & 80 \\
\hline
\end{tabular}

Tabel 4 menunjukkan bahwa subjek yang mengalami penurunan tekanan darah sistolik pada kelompok perlakuan hanya sebesar $28.57 \%$.

Tabel 5. Perbedaan rerata tekanan darah sistolik sebelum dan setelah intervensi pada kelompok perlakuan dan kelompok kontrol.

\begin{tabular}{lllll}
\hline Kelompok & Sist. pre $(\mathbf{m m H g})$ & Sist. post $(\mathbf{m m H g})$ & $\Delta(\mathbf{m m H g})$ & $\mathbf{P}$ \\
\hline Perlakuan & $138.57 \pm 8,997$ & $144.29 \pm 12.724$ & $10((-10)-20)$ & $0.231^{\mathrm{a}}$ \\
Kontrol & $130(120-200)$ & $135(120-200)$ & $0.00((-10)-$ & $0.480^{\mathrm{b}}$
\end{tabular}

${ }^{\text {aPaired-t test }}$

${ }^{b}$ Uji Wilcoxon

Tabel 5 menunjukkan bahwa secara deskriptif terdapat peningkatan tekanan darah sistolik sebelum dan setelah dilakukan intervensi pada kelompok perlakuan $((10)-20)$. Namun

secara statistik tidak terdapat perbedaan tekanan darah sistolik sebelum dan setelah dilakukan intervensi pada kedua kelompok $(\mathrm{P}>0.05)$.

Tabel 6. Karakteristik tekanan darah diastolik subjek setelah intervensi

\begin{tabular}{|c|c|c|c|c|}
\hline Kelompok & $\begin{array}{l}\text { Mengalami } \\
\text { penurunan }\end{array}$ & $\%$ & $\begin{array}{c}\text { Tidak mengalami } \\
\text { penurunan }\end{array}$ & $\%$ \\
\hline Perlakuan & 3 & 42.86 & 4 & 57.14 \\
\hline Kontrol & 4 & 40 & 6 & 60 \\
\hline
\end{tabular}


Tabel 6 menunjukkan bahwa subjek yang mengalami penurunan tekanan darah diastolik pada kelompok perlakuan hanya sebesar $42.86 \%$.

Tabel 7. Perbedaan rerata tekanan darah diastolik sebelum dan setelah intervensi pada kelompok perlakuan dan kelompok kontrol.

\begin{tabular}{lllll}
\hline Kelompok & Diast pre $(\mathbf{m m H g})$ & Diast post $(\mathbf{m m H g})$ & $\Delta(\mathbf{m m H g})$ & P $^{*}$ \\
\hline Perlakuan & $80(80-90)$ & $82.86 \pm 9.512$ & $0.00((-10)-20)$ & 0.705 \\
Kontrol & $80(80-120)$ & $82.00 \pm 9.189$ & $-4 \pm 4.833$ & 0.157 \\
\hline
\end{tabular}

*Uji Wilcoxon

Tabel 7 menunjukkan bahwa secara deskriptif terdapat penurunan tekanan darah diastolik sebelum dan setelah dilakukan intervensi pada kelompok kontrol $(-4 \pm 4.833)$. Namun secara statistik tidak terdapat perbedaan tekanan darah diastolik sebelum dan setelah dilakukan intervensi pada kedua kelompok $(\mathrm{P}>0.05)$.

Dari tabel 5 dan tabel 7 dapat disimpulkan bahwa secara statistik tidak terdapat perbedaan nilai tekanan darah sistolik dan diastolik pada kelompok perlakuan dan kelompok kontrol sebelum dan setelah dilakukan intervensi penerapan pola diet DASH.

Perbedaan nilai tekanan darah sistolik dan diastolik antara kelompok perlakuan dan kelompok kontrol setelah dilakukan intervensi disajikan dalam tabel 8 berikut ini.

Tabel 8. Perbedaan nilai tekanan darah sistolik dan diastolik antara kedua kelompok setelah dilakukan intervensi

\begin{tabular}{llll}
\hline Variabel & Perlakuan & Kontrol & p \\
\hline Tekanan darah sistolik $(\mathrm{mmHg})$ & $144.29 \pm 12.724$ & $135(120-200)$ & $0.193^{\mathrm{a}}$ \\
Tekanan darah diastolik $(\mathrm{mmHg})$ & $82.86 \pm 9.512$ & $82 \pm 9.189$ & $0.854^{\mathrm{b}}$ \\
\hline
\end{tabular}

${ }^{\mathrm{a} U j i}$ Mann-Whitney ${ }^{\mathrm{b}}$ Independent-t test

Tabel 8 menunjukkan bahwa tidak terdapat perbedaan nilai tekanan darah baik tekanan darah sistolik maupun tekanan darah diastolik antara kelompok perlakuan dan kelompok kontrol setelah dilakukan intervensi, dengan nilai masing-masing sebesar $\mathrm{P}>0.05$.

\section{PEMBAHASAN}

Subjek dalam penelitian ini merupakan kelompok lanjut usia (lansia) yang semuanya berusia 60 tahun atau lebih dan mengalami prehipertensi, hipertensi tahap I dan hipertensi tahap II. Pemilihan subjek dengan kriteria usia lanjut disebabkan adanya peningkatan usia yang berbanding lurus dengan peningkatan nilai tekanan darah. ${ }^{3,6,7,8}$ Risiko hipertensi lebih besar terjadi pada kelompok usia lanjut disebabkan oleh mekanisme berikut ini. Pada kelompok lansia terjadi penurunan elastisitas pembuluh darah perifer akibat proses penuaan sehingga akan meningkatkan resistensi pembuluh darah perifer. ${ }^{1}$ Selain itu, pada kelompok lansia terjadi peningkatan sensitivitas terhadap asupan natrium. ${ }^{1,7}$

Sebagian besar subjek memiliki status gizi normal, yaitu sebesar $52.94 \%$. Sebanyak $29.41 \%$ subjek memiliki status gizi kurang dan $17.65 \%$ subjek memiliki status gizi lebih. Sebanyak
$52.94 \%$ dan $64.70 \%$ subjek memiliki tekanan darah sistolik dan diastolik yang termasuk dalam kategori prehipertensi

Secara statistik, terdapat perbedaan signifikan mengenai asupan zat gizi selama dilakukan intervensi antara kelompok perlakuan dan kelompok kontrol, kecuali untuk asupan natrium. Asupan energi, karbohidrat, protein, lemak, kalium, magnesium, kalsium, serat, asam lemak jenuh dan kolesterol lebih tinggi pada kelompok perlakuan dibandingkan pada kelompok kontrol. Tidak terdapat perbedaan asupan natrium antara kedua kelompok disebabkan oleh jumlah garam yang digunakan dalam proses pengolahan makanan untuk kedua kelompok ditetapkan sama. Jika dibandingkan dengan pola diet DASH yang diterapkan, rerata asupan energi, karbohidrat, protein, lemak, kalium, magnesium, kalsium, serat dan kolesterol selama intervensi pada kedua kelompok lebih rendah dari energi, karbohidrat, protein, lemak, kalium, magnesium, kalsium, serat dan kolesterol yang terdapat dalam pola diet DASH. Sedangkan rerata asupan natrium pada kedua kelompok selama intervensi lebih tinggi dari natrium dalam pola diet DASH.

Pada kelompok perlakuan dan kelompok kontrol, rerata asupan energi selama intervensi masing-masing sebesar $63.1 \%$ dan $44.5 \%$ dari 
energi yang terdapat dalam pola diet DASH. Rerata asupan karbohidrat untuk kelompok perlakuan dan kelompok kontrol masing-masing $69.4 \%$ dan $39.9 \%$ dari karbohidrat dalam pola diet DASH. Rerata asupan protein untuk kelompok perlakuan dan kelompok kontrol masing-masing $69.2 \%$ dan $39.7 \%$ dari protein dalam pola diet DASH. Rerata asupan lemak untuk kelompok perlakuan dan kelompok kontrol masing-masing 91\% dan $72.6 \%$ dari lemak dalam pola diet DASH. Rerata asupan kalium untuk kelompok perlakuan dan kelompok kontrol masing-masing $65.5 \%$ dan $17.8 \%$ dari kalium dalam pola diet DASH. Rerata asupan magnesium untuk kelompok perlakuan dan kelompok kontrol masing-masing $62.5 \%$ dan $29.6 \%$ dari magnesium dalam pola diet DASH. Rerata asupan kalsium untuk kelompok perlakuan dan kelompok kontrol masing-masing $53.1 \%$ dan $16 \%$ dari kalsium dalam pola diet DASH. Rerata asupan serat untuk kelompok perlakuan dan kelompok kontrol masing-masing $76.7 \%$ dan $25.5 \%$ dari serat dalam pola diet DASH. Rerata asupan asam lemak jenuh untuk kelompok perlakuan dan kelompok kontrol masing-masing $85.9 \%$ dan $69 \%$ dari asam lemak jenuh dalam pola diet DASH. Rerata asupan natrium untuk kelompok perlakuan dan kelompok kontrol masing-masing $106.3 \%$ dan $111 \%$ dari natrium dalam pola diet DASH. Rerata asupan kolesterol untuk kelompok perlakuan dan kelompok kontrol masing-masing $82.2 \%$ dan $91 \%$ dari kolesterol dalam pola diet DASH. Dari penjelasan di atas dapat disimpulkan bahwa rerata asupan energi dan zat gizi selama intervensi pada kelompok perlakuan lebih tinggi dibandingkan pada kelompok kontrol, kecuali untuk rerata asupan natrium dan kolesterol selama intervensi yang lebih tinggi pada kelompok kontrol.

Berdasarkan hasil pencatatan asupan makan selama intervensi, dapat disimpulkan bahwa jika dibandingkan dengan kebutuhan per hari, rerata asupan energi, karbohidrat, protein, lemak, kalium, magnesium, kalsium, serat dan kolesterol pada kedua kelompok selama intervensi lebih rendah dari kebutuhan energi dan zat gizi tersebut per hari. Rerata asupan natrium pada kedua kelompok lebih tinggi dari kebuthan natrium per hari. Rerata asupan asam lemak jenuh selama intervensi pada kelompok perlakuan lebih tinggi dari kebutuhan asam lemak jenuh per hari. Pada kelompok perlakuan dan kelompok kontrol, rerata asupan energi selama intervensi masing-masing sebesar $63.2 \%$ dan $43.1 \%$ dari kebutuhan energi per hari. Rerata asupan karbohidrat untuk kelompok perlakuan dan kelompok kontrol masing-masing $77.8 \%$ dan $43.7 \%$ dari kebutuhan karbohidrat per hari. Rerata asupan protein untuk kelompok perlakuan dan kelompok kontrol masing-masing $73.2 \%$ dan $43.0 \%$ dari kebutuhan protein per hari. Rerata asupan lemak untuk kelompok perlakuan dan kelompok kontrol masing-masing $61.1 \%$ dan $47.3 \%$ dari kebutuhan karbohidrat per hari. Rerata asupan kalium untuk kelompok perlakuan dan kelompok kontrol masing-masing $49.8 \%$ dan $13.5 \%$ dari kebutuhan kalium per hari. Rerata asupan magnesium untuk kelompok perlakuan dan kelompok kontrol masing-masing $73.1 \%$ dan $31.1 \%$ dari kebutuhan magnesium per hari. Rerata asupan kalsium untuk kelompok perlakuan dan kelompok kontrol masing-masing $48.9 \%$ dan $15.8 \%$ dari kebutuhan kalsium per hari. Rerata asupan serat untuk kelompok perlakuan dan kelompok kontrol masing-masing $61.7 \%$ dan $20.6 \%$ dari kebutuhan serat per hari. Rerata asupan kolesterol untuk kelompok perlakuan dan kelompok kontrol masing-masing $64.3 \%$ dan $60.6 \%$ dari kebutuhan kolesterol per hari. Rerata asupan natrium untuk kelompok perlakuan dan kelompok kontrol masing-masing $156.1 \%$ dan $179 \%$ dari kebutuhan natrium per hari. Rerata asupan asam lemak jenuh untuk kelompok perlakuan dan kelompok kontrol masing-masing $120.2 \%$ dan $99.8 \%$ dari kebutuhan asam lemak jenuh per hari. Dari penjelasan di atas dapat disimpulkan bahwa rerata asupan energi dan zat gizi selama intervensi pada kelompok perlakuan lebih tinggi dibandingkan pada kelompok kontrol, kecuali untuk rerata asupan natrium selama intervensi yang lebih tinggi pada kelompok kontrol.

Beberapa zat gizi yang diduga dapat mempengaruhi tekanan darah antara lain adalah asam amino, natrium, kalium, magnesium, kalisum dan serat. Natrium merupakan kation utama yang terdapat dalam cairan ekstraseluler. Kadar natrium di dalam tubuh yang tinggi akan meningkatkan tekanan osmotik dan menarik cairan kembali ke darah sehingga terjadi peningkatan volume vaskular darah, volume cardiac output, dan tekanan darah arteri. Pada subjek yang mengalami hipertensi, peningkatan volume cardiac output dalam jangka waktu yang lama akan mengakibatkan konstriksi arteriol, suatu mekanisme autoregulatori yang mencegah transmisi tekanan darah sistemik menuju kapiler, sehingga volume cardiac output akan kembali normal secara bertahap. Namun, masih terjadi peningkatan resistensi vaskular perifer. ${ }^{34,35}$ Asupan kalium dapat menurunkan peningkatan tekanan darah melalui beberapa mekanisme, salah satunya 
dengan meningkatkan eksresi natrium. ${ }^{2,3}$ Bukti mengenai pengaruh magnesium dan kalsium terhadap penurunan tekanan darah tidak menghasilkan kesimpulan yang meyakinkan. Terdapat spekulasi bahwa jumlah asupan kalsium dari makanan mungkin mempengaruhi respon penekanan terhadap natrium, yang dibuktikan oleh sedikit percobaan yang menujukkan bahwa suplementasi kalsium dapat mencegah pengaruh dari tingginya asupan natrium terhadap tekanan darah. ${ }^{2,3}$

Intervensi yang dilakukan dalam penelitian ini adalah penerapan pola diet DASH selama 14 hari, dengan distribusi pemberian makanan sebanyak tiga kali makan utama dalam satu hari. Secara deskriptif terdapat dua orang $(28.57 \%)$ pada kelompok perlakuan yang mengalami penurunan tekanan darah sistolik setelah intervensi. Berdasarkan hasil pencatatan asupan zat gizi selama intervensi, satu orang subjek mengkonsumsi $61.6 \%$ energi, $61.2 \%$ karbohidrat, $67.2 \%$ protein, $83.5 \%$ lemak, $106.7 \%$ natrium, 69.7\% kalium, $71.8 \%$ magnesium, $54.1 \%$ kalsium, $80.6 \%$ serat, $77.5 \%$ asam lemak jenuh, dan $101.4 \%$ kolesterol dari jumlah yang terdapat dalam pola diet DASH yang diberikan. Sedangkan satu orang yang lain mengkonsumsi $67.3 \%$ energi, 63.9\% karbohidrat, $75.1 \%$ protein, $98.4 \%$ lemak, $106.7 \%$ natrium, $63.7 \%$ kalium, $28.8 \%$ magnesium, $46.8 \%$ kalsium, $77.1 \%$ serat, $94.1 \%$ asam lemak jenuh, dan $103.8 \%$ kolesterol dari jumlah yang terdapat dalam pola diet DASH yang diberikan.

Pada kelompok kontrol, terdapat dua orang (20\%) subjek yang mengalami penurunan tekanan darah sistolik. Berdasarkan hasil pencatatan asupan zat gizi selama intervensi, satu orang subjek mengkonsumsi $41.6 \%$ energi, $36.1 \%$ karbohidrat, $39.1 \%$ protein, $70.9 \%$ lemak, $112.6 \%$ natrium, $18 \%$ kalium, $28.2 \%$ magnesium, $15.9 \%$ kalsium, $24.4 \%$ serat, $64.2 \%$ asam lemak jenuh, dan $90.5 \%$ kolesterol dari jumlah yang terdapat dalam pola diet DASH. Sedangkan satu orang yang lain mengkonsumsi $43.7 \%$ energi, $40 \%$ karbohidrat, $37.8 \%$ protein, $69.5 \%$ lemak, $104.9 \%$ natrium, $17.9 \%$ kalium, $29 \%$ magnesium, $15.9 \%$ kalsium, $25.4 \%$ serat, $63.2 \%$ asam lemak jenuh, dan $88.3 \%$ kolesterol dari jumlah yang terdapat dalam pola diet DASH.

Secara deskriptif, dapat disimpulkan bahwa dari dua kelompok jumlah subjek yang mengalami penurunan tekanan darah sistolik lebih rendah yaitu sebanyak empat orang dibandingkan dengan jumlah subjek yang mengalami penurunan tekanan darah diastolik yaitu sebanyak tujuh orang.
Terdapat peningkatan tekanan darah sistolik yang terjadi secara terus menerus yang berbanding lurus dengan peningkatan usia. Demikian juga, tekanan darah diastolik cenderung mengalami peningkatan hingga pada usia lima puluh tahun, dan pada dekade selanjutnya cenderung mengalami penurunan. Pola ini mengakibatkan prevalensi hipertensi pada kelompok lansia didominasi oleh tingginya tekanan darah sistolik atau yang disebut hipertensi sistolik saja (ISH; Isolated Systolic Hypertension). ${ }^{6,7,36}$

Dalam penelitian ini, terdapat tiga orang subjek pada kelompok perlakuan dan tiga orang subjek dalam kelompok kontrol yang mengkonsumsi obat antihipertensi sebanyak satu kali setiap hari. Dari jumlah tersebut, satu orang subjek dalam kelompok perlakuan mengalami penurunan tekanan darah sistolik, satu orang subjek mengalami penurunan tekanan darah diastolik dan satu orang mengalami penurunan tekanan darah sistolik dan diastolik. Sedangkan dari tiga orang subjek pada kelompok kontrol yang mengkonsumsi obat antihipertensi, satu orang subjek mengalami penurunan tekanan darah sistolik dan dua orang lainnya mengalami penurunan tekanan darah diastolik.

Namun demikian, secara statisitik, tidak terdapat penurunan tekanan darah sistolik dan diastolik setelah dilakukan intervensi pada kelompok perlakuan dengan nilai $\mathrm{P}$ masing-masing 0.231 dan 0.705 dan tidak ada perbedaan nilai tekanan darah sistolik dan diastolik setelah dilakukan intervensi antara kelompok perlakuan dan kelompok kontrol dengan nilai $\mathrm{P}$ masingmasing 0.193 dan 0.854 . Hasil ini tidak sesuai dengan beberapa penelitian yang telah dilakukan sebelumnya yang menguji pengaruh pola diet DASH terhadap tekanan darah sistolik dan diastolik. $^{14,16,33}$ Hal ini dapat disebabkan oleh adanya faktor perancu dalam penelitian ini, seperti tidak disediakannya makanan selingan dalam penelitian ini. Selain itu durasi yang digunakan dalam penelitian ini terlalu singkat yaitu selama 14 hari.

\section{SIMPULAN}

Tidak ada pengaruh penerapan pola diet DASH selama empat belas hari terhadap tekanan darah sistolik dan diastolik pada kelompok lansia.

\section{SARAN}

Perlu dilakukan penelitian yang mengkaji pengaruh penerapan pola diet DASH terhadap nilai tekanan darah sistolik dan diastolik pada kelompok 
lansia dengan durasi penelitian yang lebih lama dan jumlah subjek yang lebih banyak.

\section{DAFTAR PUSTAKA}

1. Martono H. Penatalaksanaan Hipertensi Pada Usia Lanjut. Dalam: Martono H, Pranarka K, editor. Buku Ajar Boedhi-Darmojo Geriatri (Ilmu Kesehatan Usia Lanjut). Jakarta: Balai Penerbit Faklutas Kedokteran Universitas Indonesia; 2009. Hal. 495.

2. Savica V, Bellinghieri G, Kopple JD. The Effect Of Nutrition On Blood Pressure. Annu. Rev. Nutr. 2010.30:365-401.

3. Appel LJ. Diet And Blood Pressure. In: Ross AC, Caballero B, Cousins RJ, Tucker KL, Ziegler TR. Modern Nutrition And Helath Disease. 11 th ed. Wolters Kluwer; 2011. p 875.

4. Couch SC, Krummel DA. Medical Nutrition Therapy For Hypertension. In: Mahan LK, EscottStump S, editors. Krausse's Food And Nutrtition Therapy. 12 th ed. USA: Sauders; 2008. p 867878.

5. Pujol TJ, Tucker JE, Barnes JT. Diseases Of The Cardiovascular System. In: Marcia NM, Sucher KP, Roth SL. Nutrition Therapy And Pathopysiology. 2 th ed. WADSWORTH; 2010. p $288-297$.

6. Nolan CR, Schrier RW. The Kidney In Hypertension. In: Schrier RW. Renal And Electrolyte Disorders. 7 th ed. Wolters Kluwer. 2010. p 272.

7. Babatsikou F, Zavitsanou A. Epidemiology Of Hypertensiom In The Elderly. Health Science Journal. Vol. 4. 2010

8. Rahajeng E, Tuminah S. Prevalensi Hipertensi Dan Determinannya Di Indonesia. Maj Kedokt Indon, Vol. 59, No. 12, Desember 2009.

9. Kementrian Kesehatan RI. Riset Kesehatan Dasar 2013. 2013

10. Nwankwo T, Yoon SS, Burt V, Gu Q. Hypertension among adults in the united states: national health and examination survey, 2011 2012. NCHS Data Brief No. 133 October 2013

11. Knight-Klimas TC, Boullata JI. Drug-Nutrient Interaction. In : Boullata JI, Armenti VT, editors. Drug-Nutrient Interaction. New Jersey:Humana Press;2004.

12. Abdulrochim IP. Ginjal Dan Hipertensi Pada Usia Lanjut. Dalam: Martono H, Pranarka K, editor. Buku Ajar Boedhi-Darmojo Geriatri (Ilmu Kesehatan Usia Lanjut). Jakarta: Balai Penerbit Faklutas Kedokteran Universitas Indonesia; 2010. Hal. 491.

13. Vollmer WM, Sacks FM, Ard J, Appel LJ, Bray GA, Morton DGS. Effect of diet and sodium intake on blood pressure : Sub group analysis of the DASH- sodium trial. Ann Intern Med. 2001; 135:1019-1028.

14. McFall JM, Barkley JE, Gordon KL, Burzsminski N, Glickman EL. Effect of the DASH Diet on Pre- and Stage 1 Hypertensive Individuals in a FreeLiving Environment. Nutrition and Metabolic Insights. 2010:3 15-23.

15. National Institutes Of Health, National Heart, Lung and Blood Institute, U.S. Departement Of Health and Human Science. No. 06-4082. 2006.

16. Karanja N, Erlinger TP, Hwa LP, Miller ER, Bray GA. TheDASHdiet for high blood pressure : From clinical trial to dinner table. Cleveland Clinic Journal of Medicine. Vol. 71 No. 9. 2004.

17. Blumenthal JA, Babyak MA, Hinderliter A, Watkins LL, Craighead L, Lin PH, et al. Effects of the DASH Diet Alone and in Combination With Exercise and Weight Loss on Blood Pressure and Cardiovascular Biomarkers in Men and Women With High Blood Pressure. Arch Intern Med. 2010; 170(2):126 - 135.

18. Rahmayanti EM, Sutjiati E. Anjuran Kombinasi Diet DASH (Dietary Approaches To Stop Hypertension) Dan Diet Rendah Garam Pada Wanita Menapouse Dengan Hipertensi. Jurnal Kesehatan, Volume 7, No. 2 November 2009: 100 -118 .

19. Martin J. Hypertension Guidelines: Revisiting The JNC 7 Recommendation. The Journal of Lancaster General Hospital. Vol. 3 No. 3. 2008.

20. Anggara FHD, Prayitno N. Faktor-faktor yang Berhubungan dengan Tekanan Darah di Puskesmas Telaga Murni, Cikarang Barat tahun 2012. Jurnal Ilmiah Kesehatan. Vol. 5 No. 1. Januari 2013.

21. Chen L, Smith GD, Harbord RM, Lewis LJ. Alcohol Intake and Blood Pressure: A Systematic Review Implementing a Mendelian Randomization Approach. PloS Medicine. Vol. 5 No. 3. 2008.

22. Klatsky AL, Gunderson E. Alcohol and Hypertension : a review. Journal of The American Society of Hypertension. Vol. 2 No. 5. September 2008.

23. Kris-Etherton PM, Grieger JA, Hillpert KF, West SG. Milk Products, Dietary Pattern, and Blood Pressure Management. Journal of The American College of Nutrition. Vol. 28 No. 1. 2009.

24. Darwita S. Hubungan Status Gizi Dengan Kehilangan Gigi Pada Lansia Di Panti Jompo Abdi/Dharma Asih Binjai Tahun 2010. Fakultas Kedokteran Gigi Departemen Prostodonsia.2011.Diunduh dari: http://repository.usu.ac.id/handle/123456789/2261 9.

25. Almatsier S. Prinsip Dasar Ilmu Gizi. Jakarta : Gramedia Pustaka Utama ; 2009. hal. 146.

26. Sunoto, Sastroasmoro S, Munthe BG, Batubara JRL, Suyoko EMD. Penulisan Rujukan. Dalam : Sastroasmoro S, Ismael S. Dasar-dasar Metodologi Penelitian Klinis. Jakarta: Sagung Seto; 2011. hal. 359.

27. Sacks FM, Laura MD, Svetkey LP, Vollmer WM, Appel LJ, Bray GA, Et Al. Effects On Blood Pressure Of Reduced Dietary Sodium And 
Thedietary Approaches To Stop Hypertension (Dash) Diet. N Engl J Med, Vol. 344, No. 1 January 4, 2001.

28. Butte NF, Caballero B. Energy Needs: Assessment And Requirements. In: Ross AC, Caballero B, Cousins RJ, Tucker KL, Ziegler TR. Modern Nutrition And Helath Disease. 11 th ed. Wolters Kluwer; 2011. p 94-96.

29. Campbell WW, Carnell NS, Thalacker AE. Protein Metabolism And Requirements. In: Geriatric Nutrition. The Health Professional's Handbook. 3 th ed. Jones And Bartlett Publishers; 2006. p 1521.

30. Chernoff R. Carbohydrate, Fat And Fluid Requirements In Older Adults. In: Geriatric Nutrition. The Health Professional's Handbook. 3 th ed. Jones And Bartlett Publishers; 2006. p 2328.

31. Hirani V, Tabassum F, Aresu M, Mindell J. Development Of New Demi-Span Equations From A Nationally Representative Sample Of Adults To Estimate Maximal Adult Height. J. Nutr. doi: 10.3945/jn.109.118430.

32. Wiryani C, Kuswardhani T, Aryana S, Astika N, Yanson, Widana K. Hubungan Antara Sudut Kelengkungan Thorak Dan Selisih Tinggi Badan Ukur Dan Tinggi Badan Hitung Berdasarkan Tinggi Lutut Pada Pasien Usia Lanjut Di Poliklinik Geriatri Rumah Sakit Sanglah Denpasar. J Peny Dalam. Vol. 11 No. 1. Januari 2010.

33. Dahlan MS. Statistik Untuk Kedokteran Dan Kesehatan: Deskriptif, Bivariat, Dan Multivariat. Dilengkapi Dengan Aplikasi Menggunakan SPSS. Edisi ke-5. Jakarta: Salemba Medika; 2011.

34. Nelm MN. Fluid and Electrolyte Balance. In: Nelms MN, Sucher KP, Lacey K, Roth SR, editors. Nutrition Therapy and Pathopysiology. 2 th ed. WADSWORTH; 2010. p 124-125.

35. Bailey JL, Sands JM, Franch HA. Water, Electrolytes, And Acid-Base Metabolism. In: Ross AC, Caballero B, Cousins RJ, Tucker KL, Ziegler TR. Modern Nutrition And Helath Disease. 11 th ed. Wolters Kluwer; 2011. p 104.

36. Maddens M, Imam K, Ashkar A. Hypertension In The Elderly. Prim Care Clin Office Pract 32 (2005) 723-753. 